\title{
Soil physical quality changes under different management systems after 10 years in the Argentine humid pampa
}

\author{
J. L. Costa ${ }^{1}$, V. Aparicio ${ }^{1}$, and A. Cerdà ${ }^{2}$ \\ ${ }^{1}$ EEA INTA Balcarce, C. C. 276, 7620 Balcarce, Buenos Aires Province, Argentina \\ ${ }^{2}$ Soil Erosion and Degradation Research Group, Departament de Geografia, Universitat de València, Blasco Ibáñez, 28, \\ 46010-València, Spain
}

Correspondence to: V. Aparicio (aparicio.virginia@inta.gob.ar)

Received: 17 July 2014 - Published in Solid Earth Discuss.: 27 August 2014

Revised: 27 February 2015 - Accepted: 3 March 2015 - Published: 27 March 2015

\begin{abstract}
South American countries with the highest surface of land under no-tillage (NT) management are Brazil, Argentina and Chile. In Argentina, $78.5 \%$ of the agricultural land is cropped under NT management. Several experiments have confirmed the improvements in soil aggregation and infiltration achieved by NT management in dry-land farming areas associated with increases of bulk density $\left(\delta_{\mathrm{b}}\right)$ under NT management. An increase in bulk density implies a reduction of the macro and mesoporosity that is in contradiction with the increased infiltration that occurs at macro and mesopores. We hypothesize that the increase of bulk density in NT management mainly affects the mesopores. We evaluated the evolution of the soil physical parameters in three management systems in four farmers' fields. We found that the reduction in total porosity under NT management is mainly a product of a reduction in the percentage of mesopores in the soil. In this work, the results indicate a modification of some soil physical parameters (porosity, near-saturated hydraulic conductivity, soil structure) due to uninterrupted agricultural production, but the management system did not affect the yields of crop.
\end{abstract}

\section{Introduction}

Sustainable soil management in agricultural land is needed for a sustainable world. Efforts to achieve a sustainable management can be found in developed and developing countries (Perkins et al., 2013; Mekuria and Aynekulu, 2013). One of the most successful soil management techniques in agricultural land is no-tillage management (NT), and it is being ap- plied worldwide (Barbera et al., 2012; Schneider et al., 2012; Thapa and Yila, 2012; Lieskovský and Kenderessy, 2014). No-tillage management affects the pedological, hydrological and geomorphological processes (García-Orenes et al., 2009; Olang et al., 2014; Gao et al., 2014).

South American countries with the highest surface of land under NT management are Brazil, Argentina and Chile (Lal et al., 2007). In Argentina, with 33 million hectares cultivated with grain, $78.5 \%$ is cropped under NT management (Aapresid, 2012). However, the southeast section of the humid pampa, spanning 6 million hectares, $90 \%$ of which are agricultural lands, does not reflect this situation, because most of the crops are managed with tillage practices. However, NT management is becoming more popular, and little is known about the effects of this practice on soil properties.

The NT presents an important advantage when plow pans under moldboard-plow (MP) management are generated. Subsoil compaction caused changes to the root system of sunflower that affected shoot growth and crop yields (Botta et al., 2006). However, the adoption of NT techniques does not always benefits the soil. Previous work demonstrated that under NT management, the values of bulk density $\left(\delta_{\mathrm{b}}\right)$ and the penetration resistance in the superficial layers of the soil are higher than those of the plowed soils due to soil compactation (Özcan et al., 2013). Intensive soil cultivation produces decreases in soil organic carbon (SOC) content (Studdert et al., 1997; Barbera et al., 2012: Lozano-García and ParrasAlcántara, 2014; Srinivasarao et al., 2014). The magnitude of such impact depends on the intensity of the management system, the tillage timeliness and the amount and quality of the residues: stubble, roots and exudates. Adopting NT and 
Table 1. Initial soil characteristics of the experiments: $\mathrm{pH}, P$ content, soil organic carbon (SOC) stock, cation exchange capacity (CEC), sand, silt and clay content, $N=3$.

\begin{tabular}{lllllllll}
\hline Sites & $\begin{array}{l}\text { Deph } \\
\mathrm{cm}\end{array}$ & $\mathrm{pH}$ & $\begin{array}{l}P \\
\mathrm{ppm}\end{array}$ & $\begin{array}{l}\text { SOC Stock } \\
\mathrm{g} \mathrm{m}^{-2}\end{array}$ & $\begin{array}{l}\mathrm{CIC} \\
\mathrm{cmol}_{(+)} \mathrm{kg}^{-1}\end{array}$ & Sand & $\begin{array}{l}\text { Silt } \\
\%\end{array}$ & Clay \\
\hline Napaleofú & $0-20$ & $5.90(0.44)$ & $11.5(2.91)$ & $86255(8242)$ & $26.5(2.54)$ & $24.4(1.82)$ & $48.7(1.75)$ & $27.0(2.88)$ \\
Balcarce & $0-20$ & $5.83(0.49)$ & $12.2(5.5)$ & $82271(8635)$ & $22.1(1.92)$ & $36.8(2.69)$ & $44.5(2.72)$ & $18.7(3.39)$ \\
Tandil & $0-20$ & $5.82(0.43)$ & $12.2(4.54)$ & $81225(9411)$ & $24.0(0.92)$ & $25.9(1.56)$ & $46.2(3.64)$ & $27.9(4.80)$ \\
Miramar & $0-20$ & $5.77(0.47)$ & $12.8(3.24)$ & $90822(7420)$ & $25.1(3.12)$ & $29.0(2.15)$ & $50.7(2.86)$ & $20.3(3.54)$ \\
\hline
\end{tabular}

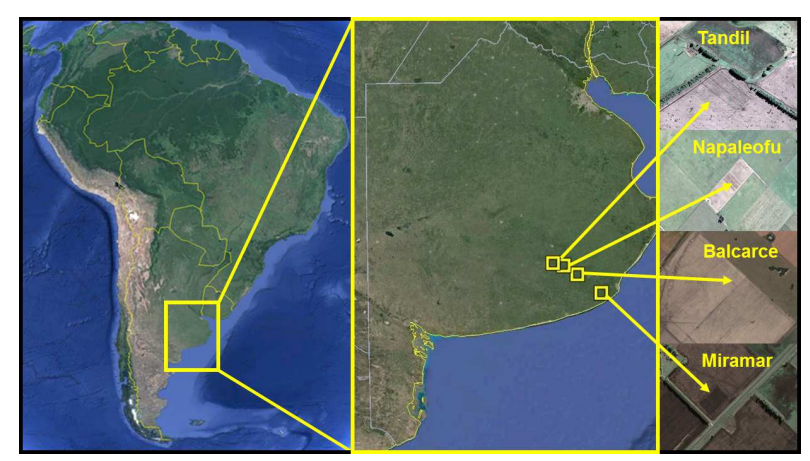

Figure 1. Experiment geographic location.

an adequate fertilization treatment may reduce the effects of intensive agriculture, through the maintenance and accumulation of SOC (Salinas-García et al., 1997) and the reduction of soil and water losses (García-Orenes et al., 2012).

Soil organic carbon has a very important role to play in other edaphic properties. Hati et al. (2006) emphasized its influence on the retention and movement of water in the soil, whereas Aparicio and Costa (2007) reported a significant and positive correlation of SOC with hydraulic conductivity $(r=0.6 ; 0.001<p<0.05)$ and a negative one with the $\delta_{\mathrm{b}}$ of the soil $(r=-0.6 ; 0.001<p<0.05)$. There is a strong relationship between soil microbiological activity, organic matter and the structural stability of the soil (García-Orenes et al., 2010). Soil aggregate formation is influenced by biotic and abiotic factors, and the SOC content plays an important role in the stabilization of aggregates and the reduction of the soil losses (Cerdà, 2000). Vegetation cover is the key factor on the control of soil erosion (Jordán et al., 2008), and on agricultural land the use of mulches under NT management is a key factor of the recovery of the soil quality (Jordán et al., 2010). The mulches used are organic (straw, chipped pruned branches) or minerals such as rock fragments mentioned by Martinez-Zavala and Jordán (2008) and Moeyersons et al. (2006) among others.

In a review from Álvarez and Steinbach (2009), a number of experiments have confirmed the improvements in soil aggregation and infiltration achieved by NT in dry-land farming areas associated with increases of $\delta_{\mathrm{b}}$ under NT management. An increase to $\delta_{\mathrm{b}}$ implies a reduction of the macro and meso- porosity which is in contradiction with the increased infiltration which occurs at macro and mesopores. We hypothesize that the increase in $\delta_{\mathrm{b}}$ in NT mainly affects the mesopores. On the other hand, averaging out soil SOC differences in various experiments under NT management showed an increase of $2.1 \mathrm{MgCha}^{-1}$ over MP, and the steady state was reached after 25-30 years (Álvarez, 2005). When enough nutrients were applied, there was no difference in yields between tillage systems.

With this scenario and the tendency to increase the surface under NT management in the southeast of the humid pampa. We aimed to evaluate the following: (i) $\delta_{\mathrm{b}}$, the change in weighted average diameter, the hydraulic conductivity and organic carbon content on wheat-corn-sunflower crop sequence in three management systems; (ii) whether pore size is affecting the differences in bulk density observed in three management systems and its relation to the soil hydraulic conductivity; (iii) yields of the crop sequence over 10 years.

\section{Materials and methods}

\subsection{Experimental site}

The Pampean region is a wide plain where Quaternary eolian sediments were partially reworked. The experimental area is located in the geological province named "Sierras Septentrionales" in the southeast of the Buenos Aires Province of Argentine (Fig. 1). The loess deposits of the SE of Buenos Aires Province are from the Late Pleistocene and Holocene. The mineralogical composition of loess consists of a volcaniclastic assemblage derived mainly from reworked pyroclastic deposits (Z'arate and Blasi, 1991). The soils are classified as Typic Argiudoll and Petrocalcic Argiudoll (Klingebiel and Montgomery, 1961) and are fine, illitic, thermal and mixed (Soil Survey Staff, 2010). The initial soil characteristics of the experiments are shown in Table 1.

The southeast of Buenos Aires Province has a mean annual temperature of $13.3^{\circ} \mathrm{C}$ and the frost-free period extends from the beginning of October to mid-May. It has a subhumid to humid hydric regime (Thornthwaite, 1948) and its rainfall regime comprises three seasons: (a) rainy from October to March, (b) moderately rainy in April, May and September, and (c) scarcely rainy from June to August. Mean annual precipitation is about $900 \mathrm{~mm}$ in the region. 


\subsection{Experiment design}

The experiment was installed in 1997 in soils managed with MP. A randomized complete block design was used for the experiment, considering each locality as a block. Each plot was $50 \mathrm{~m}$ in width by $100 \mathrm{~m}$ in length, and the treatments were NT, MP and CP. No-tillage management consisted of chemical weed control during the fallow period using glyphosate [ $N$-(phosphonomethyl) glycine] as herbicide, and seeding directly into the standing residues of the previous crop. Moldboard plow consisted of two tillage operations with a moldboard plow at a depth of $20 \mathrm{~cm}$ and two operations with disc harrow. Chisel plow management consisted of two chisel plow operations at a depth of $10 \mathrm{~cm}$ and two operations with disc harrow each year for seedbed preparation.

The crop sequence analyzed was wheat-corn-sunflower; during the experimental period three crop sequences were performed, ending with wheat. The crops were fertilized with nitrogen at the V4-V6 stage in corn, at the sowing stage in wheat, and at the star stage in sunflower.

\subsection{Soil physical and chemical analysis}

The soil physical parameters, except maximum $\delta$, were determined after wheat harvests in 2 years (2004 and 2007) during the experimental period of 10 years (1997-2007). In the wheat harvest of the year 2004 the first determination of physical parameters was performed to begin after two complete cycles of the wheat-corn-sunflower sequence under three soil management systems. This decision was made because we consider it necessary to allow a period of stabilization of the NT, since it has been suggested that between 3 and 4 years is required for soils with tillage reduced succeed in developing a favorable porosity in the first centimeters deep (Voorhees and Lindstrom, 1984) at the end of the third cycle of the crop sequence determinations of the physical parameters were again carried out during the wheat harvests in the year 2007 to analyze trends between the two periods. The methodology used was as follows.

Bulk density $\left(\delta_{\mathrm{b}}\right)$ was measured by the cylinder method (Blake and Hartge, 1986) with 12 subsamples per plot, per year and per depth. The samples' depths were 3 to 8 and 13 to $18 \mathrm{~cm}$.

Total porosity $(\rho)$ was calculated as follows:

$\rho=1-\frac{\delta_{\mathrm{b}}}{\left[\left(1-\frac{\mathrm{SOC}}{100}\right) \delta_{\mathrm{r}}+\left(\frac{\mathrm{SOC}}{100}\right) \delta_{\mathrm{OC}}\right]}$,

where $\delta_{\mathrm{r}}$ the particle density $\left(2.65 \mathrm{Mg} \mathrm{m}^{-3}\right)$, and $\delta_{\mathrm{OC}}$ is the SOC density $\left(1.3 \mathrm{Mg} \mathrm{m}^{-3}\right)$.

Maximum $\delta_{\mathrm{b}}$ was estimated from the maximum compactability using the standard Proctor method (Felt, 1965), a soil sampled from 0-20 cm depth was taken for each treatment and block in 2007. Bulk density was replaced by maximum $\delta_{\mathrm{b}}$ in Eq. (1), the resulting value was considered the textural porosity $\left(\rho_{\mathrm{t}}\right)$ (Aparicio and Costa, 2007). The $\rho_{\mathrm{t}}$ values used to calculate the structural porosity $\left(\rho_{\mathrm{s}}\right)$ as follows:

$\rho_{\mathrm{s}}=\rho-\rho_{\mathrm{t}}$

Total porosity, using Eq. (2), was calculated using the average value of $\delta_{\mathrm{b}}$ over time and depth for each treatment and block.

Change in mean weight diameter (CMWD) was measured by the De Leenheer and De Boodt (1959) method. The De Leenheer and De Boodt instability index was determined as the measured area between the two curves corresponding to the aggregate size distributions found before and after wet sieving water-moistened aggregates with diameters between 2 and $8 \mathrm{~mm}$. The authors determined the index graphically, but it is numerically equivalent to CMWD between the dry aggregate distribution and the water stable aggregate size distribution. The larger the value of CMWD, the more unstable the aggregates (Diaz Zorita et al., 2002).

Four disturbed subsamples from each plot were dry and wet sieved, obtaining the CMWD. The samples for CMWD were collected at a depth of $0-20 \mathrm{~cm}$.

Unsaturated hydraulic conductivity $\left(K_{\mathrm{h}}\right)$ was measured using a tension infiltrometer (Soil Measurement System ${ }^{\circledR}$, model SW-080B), which has a $20 \mathrm{~cm}$ diameter base-plate that was separate from the water tower. Infiltration runs were performed at matric potential $(h)$ of $-150,-70$ and $-20 \mathrm{~mm}$, and readings were made for $40 \mathrm{~min}$ at each tension, beginning with $150 \mathrm{~mm}$. The $K_{\mathrm{h}}$ was measurement using a disc infiltrometer. The $K_{\mathrm{h}}$ for each tension was taken once the equilibrium (steady-state flow) was achieved. The time required to reach steady state in unconfined infiltration measurements depends on initial soil water content and on hydraulic properties of a given soil. In general, drier soil and lower hydraulic conductivity result in the need for a longer infiltration period in order to reach steady-state infiltration. Wooding (1968) proposed the following equations to describe the three-dimensional movement of water under a disk:

$$
\begin{array}{r}
Q_{\left(K_{\mathrm{h}}\right)}=\pi r^{2} K_{\mathrm{h}}\left(1+\frac{4}{\pi r \alpha}\right) \\
K_{\mathrm{h}}=K_{\mathrm{S}} \exp (\alpha h),
\end{array}
$$

where $Q_{\left(K_{\mathrm{h}}\right)}=$ infiltrated water volume expressed in $\mathrm{cm}^{3} \mathrm{~h}^{-1}, r=$ radius of the disk in $\mathrm{cm}, K_{\mathrm{s}}=$ saturated hydraulic conductivity in $\mathrm{cm} \mathrm{h}^{-1}, K_{\mathrm{h}}=$ hydraulic conductivity at tension $h$ in $\mathrm{cm}$ and $\alpha$ is a constant. With Eq. (3) and the procedure proposed by Logsdon and Jaynes (1993), we obtained $\alpha$ to calculate $K_{\mathrm{s}}$ and $K_{\mathrm{h}}$. Hydraulic conductivity was measured with four subsamples in each plot on wheat stubble during the wheat fallow period.

The maximum number of effective pores per unit area $(N)$ was calculated using the procedure of Watson and Luxmoore (1986) and the effective porosity is given by

$\theta_{\varepsilon}=N \pi R^{2}$, 
Table 2. Effect of time: years 2004 and 2007; effect of depth: from 3 to $8 \mathrm{~cm}$ and from 13 to $18 \mathrm{~cm}$; effect of treatments: moldboard plow (MP), chisel plow (CP) and no-tillage (NT) management on soil bulk density, $N=288$.

\begin{tabular}{lrll}
\hline Effect & \multicolumn{3}{l}{$\begin{array}{l}\text { Bulk density } \\
\mathrm{Mg} \mathrm{m}^{-3}\end{array}$} \\
\hline Time & 2004 & $1.2045(0.008)$ & $\mathrm{a}^{*}$ \\
& 2007 & $1.1831(0.008)$ & $\mathrm{b}$ \\
\hline Soil depth & $3-8 \mathrm{~cm}$ & $1.2052(0.008)$ & $\mathrm{a}$ \\
& $13-18 \mathrm{~cm}$ & $1.1824(0.008)$ & $\mathrm{b}$ \\
\hline Tillage system & $\mathrm{NT}$ & $1.2204(0.010)$ & $\mathrm{a}$ \\
& $\mathrm{MP}$ & $1.1869(0.010)$ & $\mathrm{b}$ \\
& $\mathrm{CP}$ & $1.1741(0.010)$ & $\mathrm{b}$ \\
\hline
\end{tabular}

* Different letters indicate significant differences at a $p<0.05$.

where $R$ is the minimum pore radius in each class.

Soil organic carbon (SOC) was determined by the Walkley-Black procedure (Nelson and Sommers, 1982), in composite soil samples collected at a depth of 0 to $20 \mathrm{~cm}$ from 10 different places in each plot per year. Samples were air dried, ground and sieved through a $2 \mathrm{~mm}$ sieve. Results of SOC were expressed as concentration (\%) and as stock $\left(\mathrm{g} \mathrm{m}^{-2}\right)$ considering the soil $\delta_{\mathrm{b}}$ and soil depth.

\subsection{Crop yield}

Crop yield was for sunflower and corn determined by manual harvest of three subsamples of each treatment and crop, representing $10 \mathrm{~m}^{2}$ of harvest area (Noellemeyer et al., 2013). Crop yield for wheat was done by mechanical harvest, using an experimental harvester similar to one use by Velasco et al. (2012), representing $20 \mathrm{~m}^{2}$ of harvest area.

\subsection{Statistical analyses}

The Shapiro-Wilk (1965) test was used to providing evidence of normality. Under no evidence of normality log transformation of the data were made.

Analyses of variance were performed using mixed linear models (SAS Institute, Inc. 2002). The data at different years were analyzed as repeated measurement. The random effect was block and the fixed effect was soil management. The different levels of a fixed factor, such as the treatments were tested using the post hoc test pairwise comparison of the least square mean $(p<0.05)$.

\section{Results and discussion}

\subsection{Bulk density $\left(\delta_{\mathbf{b}}\right)$}

Time $(F=7.0, p<0.01)$, depth $(F=7.98, p<0.01)$ and treatment $(F=11.75, \quad p<0.001)$ had a statistically significant effect on $\delta_{\mathrm{b}}$, and there were no time-perdepth $(F=0.84, p>0.05)$, depth-per-treatment $(F=1.37$, $p>0.05)$, time-per-treatment $(F=1.84, p>0.05)$ and timeper-depth-per-treatment $(F=1.15, p>0.05)$ interactions. Bulk density decreased over the time and was low at $3-8 \mathrm{~cm}$ (Table 2). There is a hypothesis that in the first years under NT, soil $\delta_{\mathrm{b}}$ first increases and later decreases. Voorhees and Lindstrom (1984) suggested that 3 to 4 years are required for the soils with reduced tillage to be able to develop a more favorable porosity in the first $15 \mathrm{~cm}$, which would be closely related to the biological activity and proportion of plant residues. In contrast, in another long-term experiment conducted in Argentina, no statistically significant differences in $\delta_{\mathrm{b}}$ due to time were reported (Domínguez et al., 2009).

When changing the management system from conventional tillage to NT, the initial physical condition of the soil is a critical factor that can affect the soil productivity of the region under this new management system (Elissondo et al., 2001). The $\delta_{\mathrm{b}}$ values decrease over time in the three management systems studied under wheat, corn and sunflower rotation (Table 2). In addition, $\delta_{\mathrm{b}}$ was statistically different between treatments. No-tillage $\delta_{\mathrm{b}}$ higher values than those of other management system in several experiments carried out in Argentina (Aparicio and Costa, 2007; Fabrizzi et al., 2005; Ferreras et al., 2000).

Finally, we found significant differences in $\delta_{\mathrm{b}}$ in relation to the sampling depth of the sample. The average values were 1.19 and $1.21 \mathrm{Mg} \mathrm{m}^{-3}$ for the depths of 3 to 8 and 13 to $18 \mathrm{~cm}$, respectively. Bermejo and Suero (1981) reported $\delta_{\mathrm{b}}$ values that fluctuated between 1.22 and $1.26 \mathrm{Mg} \mathrm{m}^{-3}$ under continuous cropping on Typical Argiudolls in a similar region, whereas $\delta_{\mathrm{b}}$ measurements taken in a 3-year pasture were a little higher $\left(1.35 \mathrm{Mg} \mathrm{m}^{-3}\right)$. In degraded soils, within the EEA Balcarce, Ferreras et al. (2000) reported $\delta_{\mathrm{b}}$ values higher than $1.4 \mathrm{Mg} \mathrm{m}^{-3}$.

Soil $\delta_{\mathrm{b}}$ was significantly higher under NT, but no differences were detected between MP and CP management. Although with proper rotation $\delta_{\mathrm{b}}$ can be reduced in all treatments, high traffic intensity under NT (tractors used for seeding, crop protection and treatments and harvest operations) has a significant effect on increasing the $\delta_{\mathrm{b}}$. It is known that NT helps to retain a large percentage of the crop residue over the soil surface. These residues, in addition to protecting the soil, reduce soil evaporation, thereby increasing soil moisture in the upper $10 \mathrm{~cm}$. Soils under conservation tillage are wetter than those under conventional tillage (Álvarez and Steinbach, 2009). When tillage operations are performed with moist soil, the chances of soil compaction increase (Botta 
Table 3. Maximum soil density $\left(\delta_{\text {bmax }}\right)$, total porosity $(\rho)$ textural porosity $\left(\rho_{\mathrm{t}}\right)$ and structural porosity $\left(\rho_{\mathrm{S}}\right)$ under no-tillage $(\mathrm{NT})$, moldboard-plow (MP) and chisel-plow (CP) management, $N=4$.

\begin{tabular}{ccccc}
\hline Treatment & $\begin{array}{c}\delta_{\text {bmax }} \\
\mathrm{Mg} \mathrm{m}^{-3}\end{array}$ & $\rho$ & $\begin{array}{c}\rho_{\mathrm{t}} \\
\mathrm{m}^{3} \mathrm{~m}^{-3}\end{array}$ & $\begin{array}{c}\rho_{\mathrm{s}} \\
\mathrm{m}^{3} \mathrm{~m}^{-3}\end{array}$ \\
\hline NT & $1.50(0.01)$ & $0.52 \mathrm{~b}(0.01)$ & $0.42(0.01)$ & $0.11 \mathrm{~b}(0.02)$ \\
MP & $1.60(0.05)$ & $0.54 \mathrm{a}(0.05)$ & $0.38(0.02)$ & $0.16 \mathrm{a}(0.02)$ \\
CP & $1.56(0.08)$ & $0.54 \mathrm{a}(0.08)$ & $0.39(0.03)$ & $0.15 \mathrm{a}(0.03)$ \\
\hline
\end{tabular}

Different letters within the same column show significant differences among groups $(p<0.05)$. The values in parentheses are standard deviation.

et al., 2004). Consolidation in the surface horizon induced by NT may also contribute to increase $\delta_{\mathrm{b}}$ (West et al., 1990). Under MP or CP management, tillage generates artificial macropores which in turn reduce $\delta_{\mathrm{b}}$.

Structural porosity is an estimator of the percentage of pores involved in water flow; a soil is considered moderately porous when total macroporosity ranges from 10 to $25 \%$ (Pagliai, 1988). Although textural porosity measured in the year 2007 was moderate, NT structural porosity was significantly lower than the other treatments (Table 3 ).

\subsection{Change to Mean Weight Diameter (CMWD)}

The time had a statistically significant effect on CMWD $(F=70.18, p<0.001)$, while treatment $(F=2.95, p>0.05)$ had no effects on CMWD, and the time-per-treatment interaction was significative $(F=3.12, p<0.05)$ (Fig. 2). The CMWD in 2007 increased significantly compared to 2004 in all the management systems evaluated, indicating a decrease in the structural stability of the soil due to the agricultural activities. However, the time-per-treatment interaction indicates that the MP system suffered a higher difference in the values of CMWD that the NT recorded the lowest value, and MP and NT management was no different from CP management. The CMWD increased between 2004 and 2007 as the management system became more intensive (MP $>\mathrm{CP}>\mathrm{NT}$ ) (Fig. 2). In agreement with our results, Castro Filho et al. (2002) reported higher rates of aggregate stability under NT compared with CT management. These authors suggest that the NT had the best aggregation indices for the $0-20 \mathrm{~cm}$ layer due to the increase in the organic carbon content.

Working in similar soils of the present work, Aparicio and Costa (2007) reported that CMWD accounted for $36 \%$ of the variability in the number of years under continuous agriculture, thus becoming the only physical parameter related to the years of agriculture. The CMWD was significantly higher in MP than in NT management in 2007 but was not significantly different in 2004. The CMWD was found to be higher in MP than in NT management(Aparicio and Costa, 2007; Gómez et al., 2001), whereas no differences were found between MP and NT management in degraded soils (Ferreras et al., 2000) or between $\mathrm{CP}$ and NT management in non-degraded soils

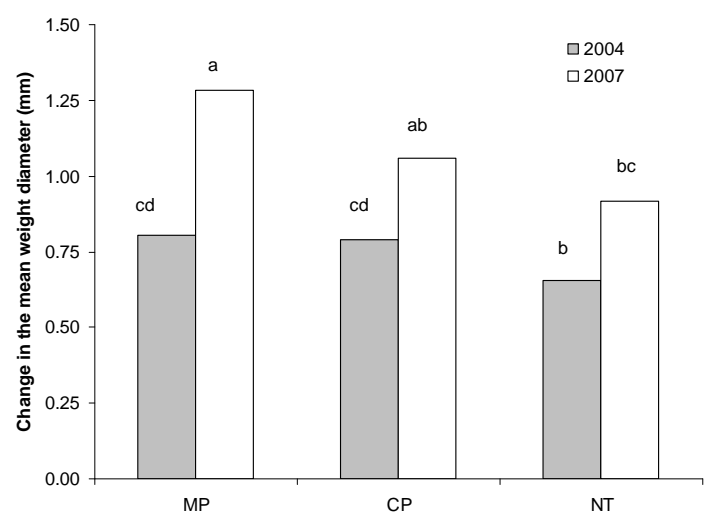

Figure 2. Effect of time on change in the mean weight diameter (CMWD, mm). Different letters indicate significant differences $(p<0.05)$.

(Elissondo et al., 2001). The latter authors pointed out that adopting CP management in a soil with a good initial physical condition does not lead to important changes in the soil structure.

In the Argentine humid pampa, the increase in structural stability that took place due to the adoption of NT was agriculturally significant. The soils under NT management are less susceptible to water erosion and soil crusting and as a consequence can store a higher amount of water for crops. After 11 years implementing the NT system in Mollisols with silty clay loam in the north of the humid pampa, Micucci and Taboada (2006) observed a recovery of the CMWD, which reached values similar to those obtained in a pasture.

Gramineous crops (wheat and corn) leave a large amount of stubble on the soil surface after the harvest. The absence of tillage and the accumulation of plant residue in the soils under NT management have contributed to reducing the loss of structural stability as a consequence of continuous cropping. Similar results have been reported with corn-wheat-soybean and wheat-soybean crop sequences (Gómez et al., 2001).

\subsection{Near-saturated Hydraulic Conductivity $\left(K_{(h)}\right)$}

We did not find significant differences in time and treatments in $K_{(0)}(F=1.81, p>0.05 ; F=1.11, p>0.05)$ and $K_{(-20)}(F=0.4, p>0.05 ; F=1.45, p>0.05)$ respectively, but we did find significant differences in time and treatments in $K_{(-70)}(F=4.56, p<0.05 ; F=7.41, p<0.01)$ and $K_{(-150)}(F=6.04, p>0.05 ; F=5.68, p>0.01)$, respectively (Fig. 3a). No interactions were detected between time and treatments in all water $h$ tested.

Differences of $K_{(\mathrm{h})}$ between treatments were not the same over the range of applied $h$; at near to saturation conditions $(h=-20 \mathrm{~mm})$, there were no significant differences. However, with more negative $\mathrm{h}$, differences between treatments occurred. At $h=-70 \mathrm{~mm}$, the measured $K_{(\mathrm{h})}$ values were greater for CT and MP management and signifi- 
Table 4. Effective porosity calculated for each pore class and tillage treatment: moldboard plow (MP), chisel plow (CP), and no tillage (NT).

\begin{tabular}{cccc}
\hline Treatment & $R^{*}>0.7$ & $\begin{array}{c}0.7>R>0.2 \\
\mathrm{~m}^{3} \mathrm{~m}^{-3}\end{array}$ & $0.2>R>0.1$ \\
\hline NT & 0.00013 & 0.0007 & 0.024 \\
MP & 0.00015 & 0.0010 & 0.045 \\
CP & 0.00009 & 0.0008 & 0.055 \\
\hline
\end{tabular}

* $R$ is the pore radius $(\mathrm{mm})$

cantly smaller for NT management. At $h=-150 \mathrm{~mm}$, the measured $K_{(\mathrm{h})}$ values were greater for CT and significantly smaller for NT and MP management. This finding agrees with $\mathrm{Hu}$ et al. (2009) on an entisol from Shenmu County, China, and Schwen et al. (2011) on a silt loam soil from Austria.

Other authors have reported lower $K$ under NT than under MP management (Ferreras et al., 2000). In a review of Álvarez and Steinbach (2009), the authors conclude from several experiments that the infiltration rate was significantly higher under NT than in MP management.

Differences of $K_{(\mathrm{h})}$ between years had a similar behavior than differences between treatments (Fig. 3b), and close to saturation $(\mathrm{h}=0$ and $h=-20)$ differences among time were not significant. However, at $h=-70$ and $h=-150$, the $K_{(\mathrm{h})}$ reduced with time when water flow was dominated by mesopores. In a study carried out in the southeast of the humid pampa, a significant decrease in $K_{(-40)}$ was observed as the number of years of continuous agriculture increased $\left(R^{2}=0.70\right)$, when the determinations were carried out under NT management in a fallow period after a wheat crop (Aparicio and Costa, 2007).

The hydraulic conductivity values are heavily affected by temporal variability. After plowing, the soil infiltration for MP or CP is very high compared to NT management, but over time the tilled soil is consolidated due to natural compaction and its hydraulic conductivity decreases. This temporal dynamic should be considered when modeling soil water flow (Strudley et al., 2008). To avoid that, in this study, the determinations were always carried out on wheat fallow, as far apart from the last tillage as possible, in order to evaluate only the cumulative effect of the different treatments in the soil properties.

The decrease in NT $K_{-70}$ and $K_{-150}$ is consistent with the low value of structural porosity and the high value of $\delta_{\mathrm{b}}$ (Table 3). The main impact of different techniques on soil hydraulic properties is expected to occur in the structural pores, macropores and mesopores. The pore classification of Luxmoore (1981) was used, where macropores have a pressure head range $h>-30 \mathrm{~mm}$ and mesopores $-30 \mathrm{~mm}\langle h\rangle-0.003 \mathrm{~mm}$, corresponding to a pore radii of $R>0.5 \mathrm{~mm}$ for macropores and $0.5 \mathrm{~mm}>R>0.005 \mathrm{~mm}$ for
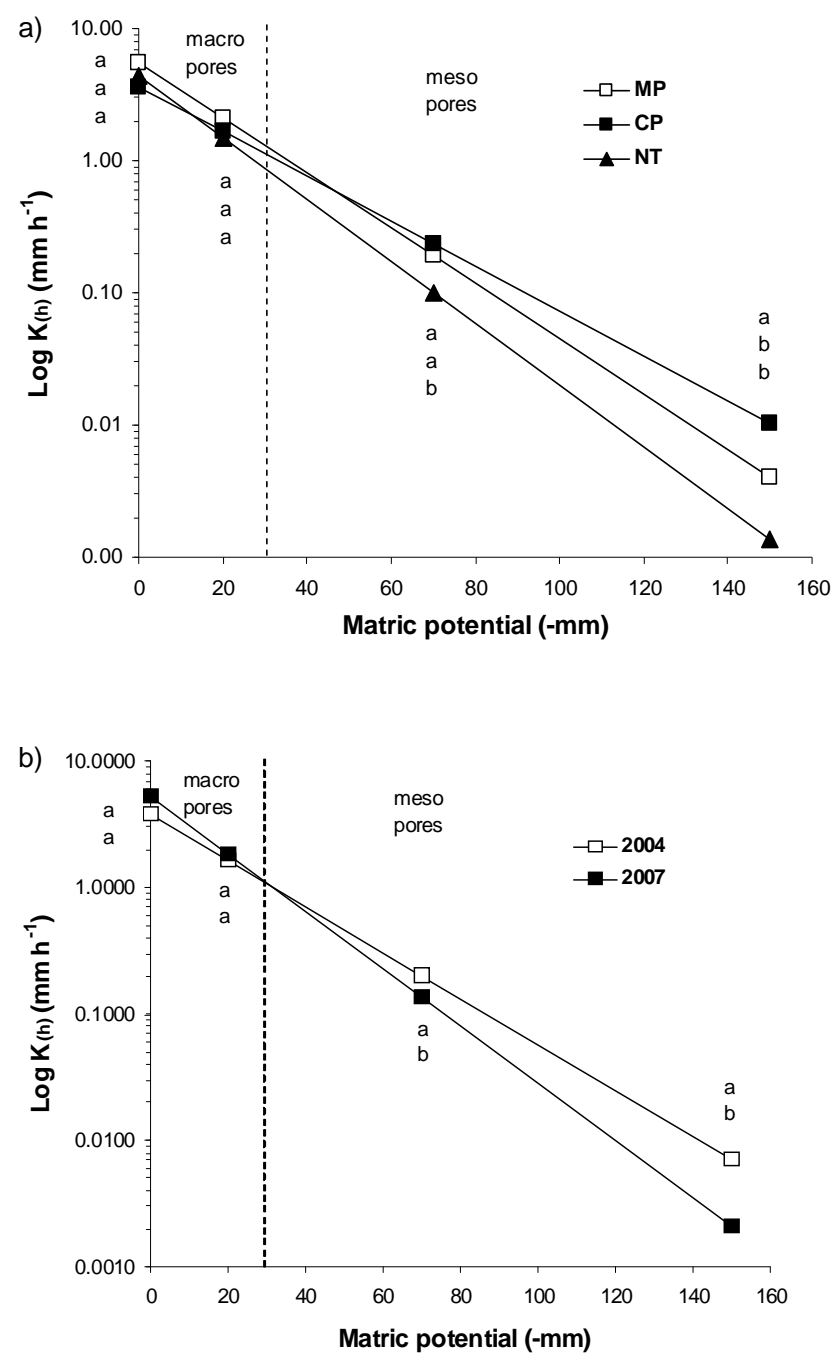

Figure 3. Near-saturated hydraulic conductivity $K_{(\mathrm{h})}$ as a function of the matric potential $(h)$. (a) of the treatments: moldboard plow (MP), chisel plow (CP) and no tillage (NT) and (b) of the time (years 2004, 2007). Different letters indicate significant differences among treatments $(p<0.05)$.

mesopores. The lower values of $K_{\mathrm{h}}$ for NT were found when water flow was dominated by mesopores $(h>-30)$.

Moldboard plow created macro and mesoporosity in the top soil layer, while macroporosity showed a considerable reduction after harvest. As time elapses after the last plowing, through reconsolidation processes, the macropores decrease, but the mesopores are kept intact. In NT, the cumulative effect of the passage of machinery exerts a direct physical action upon the soil which affects both macropores and mesopores. However, macroporosity increases. This increase could be due to the fact that biological activity (the decaying roots from the predecessor crop, wheat, and the earthworms) plays a very important role in macropore origin (Shirmohammadi and Skaggs, 1984). This biological activity effect overlays the effect of structure reconsolidation. Bodner et 


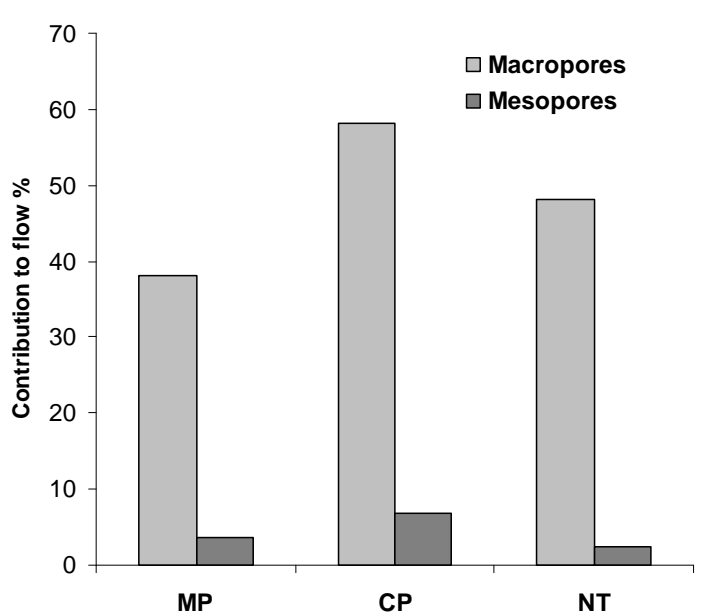

Figure 4. Comparison of pores' contribution to flow (\% of the total flow) among different tillage treatments: moldboard plow (MP), chisel plow (CP), and no tillage (NT).

al. (2014) demonstrated that plant roots conditioned soil pore properties via pore stabilization, macropore formation upon coarse root penetration and pore space heterogenization by dense fine root growth. Although macroporosity is a very small fraction of total porosity, it is responsible for the largest fraction of the water fluxes (Table 4 and Fig 4). The increase of $\delta_{\mathrm{b}}$ of the soil under NT management implies a decrease in the $\rho_{\mathrm{t}}$ (Table 3). This decrease in $\rho_{\mathrm{t}}$ should be reflected in a decrease in infiltration. However, some authors report an increase in infiltration associated with an increase in $\delta_{\mathrm{b}}$ (Álvarez and Steinbach, 2009) (this would appear to be a contradiction from a physical point of view). The data provided in this study show that when water flow is produced through macropores, there is no difference between soil under NT management and tilled soils; significant differences between treatments are only found when water flow is produced via mesopores (Fig. 3a). As the water flow via mesopores accounts for a small percentage of total water flow (Fig. 4), we can attribute to this the fact that in some studies no significant differences were found in infiltration between soil under NT management and tilled soils even though $\rho_{\mathrm{t}}$ is less. We can, therefore, conclude that the reduction in $\rho_{\mathrm{t}}$ under NT management is mainly a product of a reduction in the percentage of mesopores in the soil.

\subsection{Soil organic carbon (SOC)}

Time $(F=0.19 ; p>0.05)$ had no statistically significant effect on the SOC content when expressed either as a concentration or as SOC stock. The SOC content, did not show a statistically significant effect among management systems $(F=5.07 ; p<0.05)$ while, when the results were expressed as a stock; NT management presented the higher stock of SOC than the other treatments (Fig. 5). Álvarez (2005) suggested that, at the same sampling depth, in soils under NT

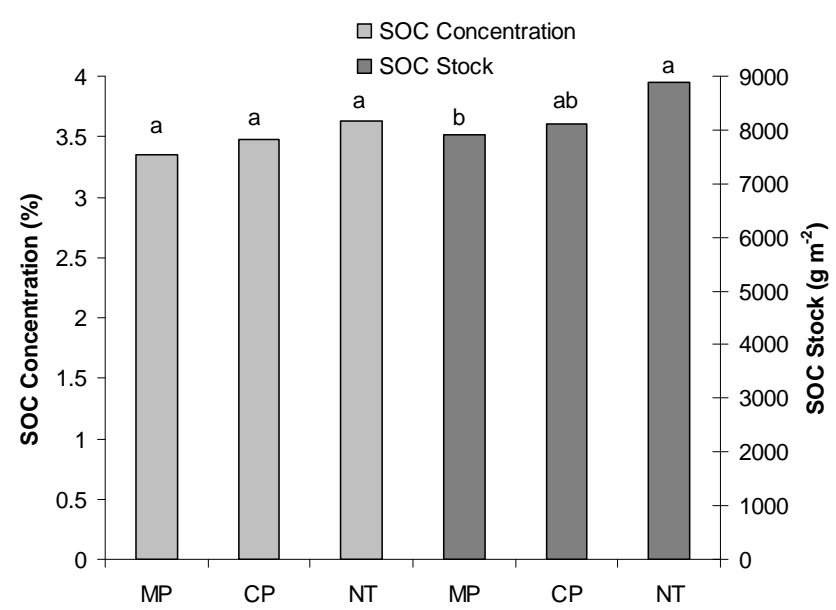

Figure 5. Soil organic carbon (SOC, \%) in the principal axes and soil organic carbon stock (SOC, $\mathrm{g} \mathrm{m}^{-2}$ ) in the secondary axes of the treatments: moldboard plow (MP), chisel plow (CP) and no till (NT). Different letters indicate significant differences among treatments $(p<0.05)$.

management, a larger amount of soil mass is sampled compared to other management systems, because in NT the $\delta_{\mathrm{b}}$ is generally higher than in other tillage systems. Thus, the SOC stock could be overestimated. In the current study, MP and CP management presented the lowest values of $\delta_{\mathrm{b}}$, and the SOC stock was significantly lower from NT management, which showed the highest values of $\delta_{\mathrm{b}}$.

The stock and the concentration of SOC followed the same trend as the concentration. When the content of SOC is expressed in stock, the experimental error is reduced, compared to expressing it as a concentration. Using SOC as stock made it possible to detect statistically significant differences between NT and the other treatments.

In the southeast of the humid pampa, Domínguez et al. (2009) have reported that the SOC content expressed both as concentration and as stock, was not affected by the tillage systems. Moreover, after 11 years of cropping under MP management, Studdert and Echeverría (2000) found a decrease in the soil SOC content. The high SOC content that characterizes the soils of the southeast of the humid pampa may be preserved by means of both a careful choice of the crops to be included in the rotation and pastures (Studdert et al., 1997). Also the use of conservation tillage systems reduces the SOC loss (Havlin et al., 1990; Eghaball et al., 1994).

In the subhumid pampa, Díaz Zorita and Grove (1999b) observed an accumulation of SOC in no-tilled soils 4 years after the implementation of this tillage system. When the proportion of corn in the crop sequence was higher, the accumulation of SOC content tended to increase. In an analysis of mega environments, involving test data distributed in several sites across the Argentine pampas, Álvarez (2005) observed an increase in the SOC content in NT and till. Fabrizzi et 


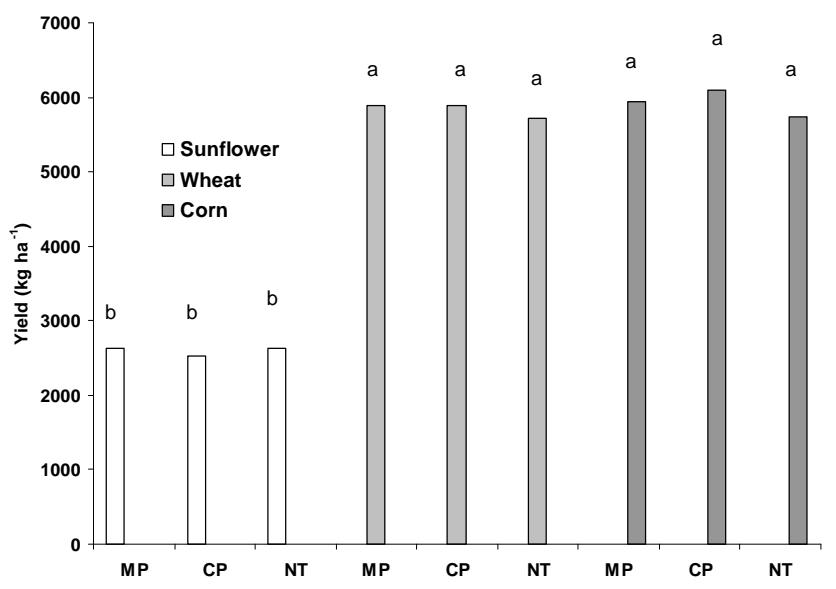

Figure 6. A total of 10 years of average grain yield for sunflower, corn and wheat under moldboard-plow (MP), chisel-plow (CP) and no-till (NT) management. Different letters indicate significant differences $(p<0.05)$.

al. (2003) have reported increases in the SOC content in NT when the soil was degraded after 8 years of continuous agriculture, but not in non-degraded soils with 5 years of continuous agriculture.

The contributions of different rates of wheat $\left(2.18 \mathrm{Mgha}^{-1}\right)$, corn $\left(1.26 \mathrm{Mgha}^{-1}\right)$ and sunflower $\left(0.96 \mathrm{Mg} \mathrm{ha}^{-1}\right)$ residues were similar among the management systems and did not explain the difference of stock found between NT and the other treatments (Álvarez, 2005). This result is also supported by the absence of significant differences in crop yield among the different management systems (Fig. 5). Our results showed that most of the SOC stock in NT, as compared to that in MP and CP management, may cause this effect of reduction in the losses of SOC, whereas in MP and CP management, similar contributions were lost rapidly by effect of the tillage.

Whereas a significant difference was detected in the SOC stock after the 10-year experiment, we could assume that, as suggested by Steinbach and Álvarez (2005), this difference is due to an overestimation by considering higher soil mass in NT.

\subsection{Crop yield}

By analyzing the crop yield of the first 10 years of this work, we found that the management system $(F=0.3 ; p>0.05)$ did not significantly affect crop yield (Fig. 6). The crop yield in the wheat-corn-sunflower rotation does not behave differently depending on the management system in which they are developed.

The absence of effect of the management system on crop yield has been previously reported for the humid pampa (Domínguez et al., 2009; Fabrizzi et al., 2005; Elissondo et al., 2001) as well as for other regions of Argentina (Díaz Zorita et al., 2002). However, in the subhumid and semi- arid pampas, the crop yields of soybean, wheat and sorghum have been found to be higher with conservation tillage systems (NT and CP). Corn and sunflower have not evidenced the same result (Buschiazzo et al., 1999). Díaz Zorita et al. (2002) in the subhumid area, found that the yields were favorable to NT only after a 5-year sequence. The semi-arid and subhumid pampas predominant soils are Hapludol and Haplustol, and the precipitations do not meet the requirements of water needed by the crops and thus normally limit the yield in MP management. The higher moisture content in NT management in the first $10 \mathrm{~cm}$ of soil in semi-arid areas makes a significant difference in yields (Quiroga et al., 2005). Changes in crop production were also found in other regions due to land management (Ahmad et al., 2013; Nabahungu and Visser, 2013).

\section{Conclusions}

The continuous agricultural activity for the last 10 years in the humid pampa is changing the soil properties. These changes were due to different land management systems.

1. The $\delta_{\mathrm{b}}$ values showed a tendency to decrease over time in the three management systems studied under wheatcorn-sunflower rotation. In addition, soil $\delta_{\mathrm{b}}$ was significantly higher under NT management, but no changes were detected between MP and CP management. The $\delta_{\mathrm{b}}$ values showed differences in relation to the sampling depth of the sample.

2. The CMWD values showed a decrease in the structural stability of the soil due to the agricultural activities. The CMWD increased more between 2004 and 2007 as the management system became intensive (MP $>\mathrm{CP}>\mathrm{NT}$ ).

3. We did not find significant differences in time and treatments in $K_{(0)}$ and $K_{(-20)}$ but we did find significant differences in time and treatments in $K_{(-70)}$ and $K_{(-150)}$. The decrease in NT $\mathrm{K}_{-70}$ and $K_{-150}$ was consistent with the low value of structural porosity and the high value of $\delta_{\mathrm{b}}$. We can conclude that the reduction in $\rho_{\mathrm{t}}$ under NT management is mainly a product of a reduction in the percentage of mesopores in the soil.

4. No statistically significant effect on the SOC content when expressed either as a concentration or as SOC stock. The SOC content, expressed as a concentration $(\%)$, did not show a statistically significant effect among management systems while, when the results were expressed as a stock, NT management presented the higher stock of SOC than the other treatments;

5. The management system did not affect the yields of the wheat-corn-sunflower crop rotation. 
Acknowledgements. We express our gratitude to the farmers for supporting part of this study and to Luis Alonso, technician at EEA INTA Balcarce for his collaboration. The experiment was conducted with funding from the INTA Project, PNCER 022411. We express our gratitude to Paulo Pereira for your excellent review of this manuscript.

Edited by: P. Pereira

\section{References}

Aapresid: Evolución de la superficie en siembra directa en Argentina. Campanas 1977/78 a 2010/11, Asociación Argentina de Productores en Siembra Directa, available at: http://www.aapresid.org.ar/wp-content/uploads/2013/02/ aapresid.evolucion_superficie_sd_argentina.1977_a_2011.pdf, (last access: 18 August 2014), 2012.

Ahmad, S., Ghafoor, A., Akhtar, M. E., and Khan, M. Z.: Ionic displacement and reclamation of soline-sodic soils using chemical amendments and crop rotation, Land Degrad. Dev., 24, 170-178, doi:10.1002/ldr.1117, 2013.

Álvarez, R.: A review of nitrogen fertilizer and conservation tillage effects on soil organic carbon storage, Soil Use Manage., 21, 3852, 2005.

Álvarez, R. and Steinbach, H. S.: A review of the effects of tillage systems on some soil physical properties, water content, nitrate availability and crops yield in Argentine Pampas, Soil Till. Res., 104, 1-15, 2009.

Aparicio, V. and Costa, J. L.: Soil quality indicators under continuous cropping systems in the Argentinean Pampas, Soil Till. Res., 96, 155-165, 2007.

Barbera, V., Poma, I., Gristina, L., Novara, A., and Egli, M.: Longterm cropping systems and tillage management effects on soil organic carbon stock and steady state level of C sequestration rates in a semiarid environment, Land Degrad. Dev., 23, 82-91, doi:10.1002/ldr.1055. 2012.

Bermejo, V. M. and Suero, E. E.: Infiltración en suelos argiudoles de Balcarce, Rev. Investig. Agropecuarias, 16, 205-213, 1981.

Bodner, G., Leitner, D., and Kaul, H. P.: Coarse and fine root plants affect poro size distribution differently, Plant Soil, 380, 133-151, 2014.

Blake, G. R and Hartge, K. H.: Bulk density, in: Methods of soil analysis, Part 1. Physical and mineralogical methods, 2nd Edition, edited by: Klute, A., American Society of Agronomy, Madison, WI, USA, 363-375, 1986.

Botta, G., Jorajuría, D., Balbuena, R., and Rrosatto, H.: Mechanical and cropping behavior of direct drilled soil under different traffic intensities: effect on soybean (Glycine max L.) yields soil, Soil Till. Res., 78, 53-58, 2004.

Botta, G. F., Jorajuria, D., Balbuena, R., Ressia, M., Ferrero, C., Rosatto, H., and Tourn, M.: Deep tillage and traffic effects on subsoil compaction and sunflower (Helianthus annus L.) yields, Soil Till. Res., 91, 164-172, 2006.

Buschiazzo, D., Panigatti, J. L., and Unger, P. W.: Tillage effects on soil properties and crop production in the subhumid Argentinean Pampas, Soil Till. Res., 49, 105-116, 1999.

Castro Filho, C., Lourenco, A., Guimaraes, M. de F., and Fonseca, I. C. B.: Aggregate stability under different soil management sys- tems in a red latosol in the state of Parana, Brazil, Soil Till. Res., 65, 45-51, 2002.

Cerdà, A.: Aggregate stability against water forces under different climates on agriculture land and scrubland in southern Bolivia, Soil Till. Res., 36, 1-8, 2000.

De Leenheer, L. and De Boodt, M.: Determination of aggregate stability by the change in mean weight diameter, in: Proceedings of the International Symposium on Soil Structure, Medelingen van de Landbouhogeschool, Ghent, 290-300, 1959.

Díaz Zorita, M. and Grove, J. H.: Crop sequence effects on the properties of two soils from disparate temperate regions under continuous no-tillage, in: American Society of Agronomy - Crop Science Society of America-Soil Science Society of America, Annual Meetings Abstracts, ASA-CSSA-SSSA, Salt Lake City, UT, USA, p. 281, 1999.

Díaz Zorita, M., Duarte, G. A., and Grove, J. H.: A review of no-till systems and soil management for sustainable crop production in the subhumid and semiarid Pampas of Argentina, Soil Till. Res., 65, 1-18, 2002.

Domínguez, G. F., Diovisalvi, N., Studdert, G., and Monterubbianesi, D.: Soil organic $\mathrm{C}$ and $\mathrm{N}$ fractions under continuous cropping with contrasting tillage systems on mollisols of the southeastern Pampas, Soil Till. Res., 102, 93-100, 2009.

Eghaball, B., Mielke, L. N., McCallister, D. L., and Doran, J. W.: Distribution of organic carbon and inorganic nitrogen in a soil under various tillage and crop sequences, J. Soil Water Conserv., 49, 201-205, 1994.

Elissondo, E., Costa, J. L., Suero, E., Fabrizzi, K. P., and Garcia, F.: Evaluación de algunas propiedades fisicas de suelos luego de la introducción de labranzas verticales en un suelo bajo siembra directa, Ciencia del Suelo, 19, 11-19, 2001.

Fabrizzi, K. P., Morón, A., and Garcia, F. O.: Soil Carbon and Nitrogen Organic Fractions in Degraded vs. Non-Degraded Mollisols in Argentina, Soil Sci. Soc. Am. J., 67, 1831-1841, 2003.

Fabrizzi, K. P., Garcia., F. O., Costa, J. L., and Piconne, L. I.: Soil water dynamics, physical properties and corn and wheat responses under minimum and no-tillage systems in the southern pampas of Argentina, Soil Till. Res., 81, 57-69, 2005.

Felt, E. J.: Compactibility, in: C. A. Black, Methods of Soil Analysis, Part 1, Agronomy, 9, 400-412, 1965.

Ferreras, L. A, Costa, J. L., Garcia, F. O., and Pecorari, C.: Effect of no-tillage on some soil physical properties of a structural degraded Petrocalcic Paleudoll of the southern "Pampa" of Argentina, Soil Till. Res., 54, 31-39, 2000.

Gao, X., Wu, P., Zhao, X., Wang J., and Shi, Y.: Effects of land use on soil moisture variation in a semi-arid catchment: implications for land and agricultural water management, Land. Degrad. Dev., 25, 163-172, doi:10.1002/ldr.1156, 2014.

García-Orenes, F., Cerdà, A., Mataix-Solera, J., Guerrero, C., Bodí, M. B., Arcenegui, V., Zornoza, R., and Sempere, J. G.: Effects of agricultural management on surface soil properties and soilwater losses in eastern Spain, Soil Till. Res., 106, 117-123. doi:10.1016/j.still.2009.06.002, 2009.

García-Orenes, F., Guerrero, C., Roldán, A., Mataix-Solera, J., Cerdà, A., Campoy, M., Zornoza, R., Bárcenas, G., and Caravaca, F.: Soil microbial biomass and activity under different agricultural management systems in a semiarid Mediterranean agroecosystem, Soil Till. Res., 109, 110-115, doi:10.1016/j.still.2010.05.005, 2010. 
García-Orenes, F., Roldán, A., Mataix-Solera, J., Cerdà, A., Campoy, M., Arcenegui, V., and Caravaca, F.: Soil structural stability and erosion rates influenced by agricultural management practices in a semi-arid Mediterranean agro-ecosystem, Soil Use Manage. 28, 571-579, doi:10.1111/j.1475-2743.2012.00451.x, 2012.

Gomez, E., Ferreras, L., Toresani, S., Ausilio, A., and Bisaro, V.: Changes in some soil properties in a Vertic Argiudoll under short-term conservation tillage, Soil Till. Res., 61, 179-186, 2001.

Hati, K. M., Swarup, A., Singh, D., Misra, A. K., and Ghosh, P. K.: Long-term continuous cropping, fertilization, and manuring effects on physical properties and organic carbon content of a sandy loam soil, Aust. J. Soil Res., 44, 487-495, 2006.

Havlin, J. L., Kissel, D. E., Maddux, L. D., Claasen, M. M., and Long, J. H.: Crop rotation and tillage effects on soil organic carbon and nitrogen, Soil Sci. Soc. Am. J., 54, 448-452, 1990.

Hu, W., Shao, M, Wang, Q., Fan, J., and Horton, R.: Temporal changes of soil hydraulic properties under different land uses, Geoderma, 149, 355-366, 2009.

Jordán, A., Martínez-Zavala, L., and Bellinfante, N.: Heterogeneity in soil hydrological response from different land cover types in southern Spain, Catena, 74, 137-143, 2008.

Jordán, A., Zavala, L. M., and Gil, J.: Effects of mulching on soil physical properties and runoff under semi-arid conditions in southern Spain, Catena, 81, 77-85, 2010.

Klingebiel, A. A. and Montgomery, P. H.: Land capability classification, in: USDA Handbook, Vol. 210, USDA, 21 pp., 1961.

Lal, R., Reicosky, D. C., and Hanson, J. D.: Evolution of the plow over 10000 years and the rationale for no-till farming, Soil Till. Res., 93, 1-12, 2007.

Lieskovsky, J. and Kenderessy, P.: Modelling the effect of vegetation cover and different tillage practices on soil erosion in vineyards: a case study in VRÁBLE (SLOVAKIA) using watem/sedem, Land Degrad. Dev., 25, 288-296, doi:10.1002/ldr.2162, 2014.

Logsdon, S. D. and Jaynes, D. B.: Methodology for determining hydraulic conductivity with tension infiltrometers, Soil Sci. Soc. Am. J., 57, 1426-1431, 1993.

Lozano-García, B. and Parras-Alcántara, L.: Variation in soil organic carbon and nitrogen stocks along a toposequence in a tradicional Mediterranean olive grove, Land Degrad. Dev., 25, 297304, doi:10.1002/ldr.2284, 2014

Luxmoore, R. J.: Micro, meso, and macroporosity of soil, Soil Sci. Soc. Am. J., 45, 671-672, 1981.

Martínez-Zavala, L. and Jordán, A.: Effect of rock fragment cover on interrill soil erosion from bare soils in Western Andalusia, Spain, Soil Use Manage., 24, 108-117, 2008.

Mekuria, W. and Aynekulu, E.: Exclosure land management for restoration of the soils in degrade communal grazing lands in Northern Ethiopia, Land Degrad. Dev., 24, 528-538, doi:10.1002/ldr.1146, 2013.

Micucci, F. G. and Taboada, M. A.: Soil physical properties and soybean (Glycine max, Merrill) root abundance in conventionallyand zero-tilled soils in the humid Pampas of Argentina, Soil Till. Res., 86, 152-162, 2006.

Moeyersons, J., Nyssen, J., Poesen, J., Deckers, J., and Haile, M.: On the origin of rock fragment mulches on Vertisols: A case study from the Ethiopian highlands, Geomorphology, 76, 411429, 2006.

Nabahungu, N. L. and Visser, S. M.: Farmers' Knowledge and perception of agricultural wetland in Rwanda, Land Degrad. Dev., 24, 363-374, doi:10.1002/ldr.1133, 2013.

Nelson, D. W. and Sommers, L. E.: Total carbon, organic carbon and organic matter, in: Page A. L. (Ed.), Methods of soil analysis, Part 2, 2nd Ed., Agron. Monogr., 9, ASA and SSSA, Madison, WI, 39-579, 1982.

Noellemeyer, E., Fernández, R., and Quiroga, A.: Crop and Tillage Effects on Water Productivity of Dryland Agriculture in Argentina, Agriculture, 3, 1-11, doi:10.3390/agriculture3010001, 2013

Olang, L. O., Kundu, P. M., Ouma, G., and Fürst, J.: Impacts of land cover change scenarios on storm runoff generation: a basis for management of the Nyando basin, Kenya, Land Degrad. Dev., 25, 267-277, doi:10.1002/ldr.2140, 2014.

Özcan, M., Gökbulak, F., and Hizal, A: Exclosure effects on recovery of selected soil properties in a mixed bradleaf recreation site, Land Degrad. Dev., 24, 266-276, doi:10.1002/ldr.1123, 2013.

Pagliai, M.: Soil porosity aspects, Int. Agrophys., 4, 215-232, 1988.

Perkins, J., Reed, M., Akanyang, L., Atlhopheng, J., Chanda, R., Magole, L., Mphinyane, W., Mulale, K., Sebego, R., Fleskens, L., Irvine, B., and Kirkby, M.: Making land management more sustainable: Experience implementing a new methodological framework in Botswana, Land Degrad. Dev., 24, 463-477, doi:10.1002/ldr.1142, 2013.

Quiroga, A., Funaro, D., Fernández, R., and Noellemeyer, E... Factores edáficos y de manejo que condicionan la eficiencia del barbecho en la región pampeana, Ciencia del Suelo, 23, 79-86, 2005.

Salinas-García, J. R., Hons, F. M., and Matocha, J. E.: Long-term effects of tillage and fertilization on soil organic matter dynamics, Soil Sci. Soc. Am. J., 61, 152-159. 1997.

SAS Institute, Inc. SAS user's guide, SAS Institute, Inc., Cary, NC, 2002.

Schneider, F., Steiger, D., Ledermann, T., Fry, P., and Rist, S.: No-tillage farming: co-creation of innovation through network building, Land Degrad. Dev., 23, 242-255, doi:10.1002/ldr.1073, 2012.

Schwen, A., Bodner, G., Scholl, P., Buchan, G., and Loiskandl, W.: Temporal dynamics of soil hydraulic properties and the waterconducting porosity under different tillage, Soil Till. Res, 113, 89-98, 2011.

Shapiro S. S. and Wilk, M. B.: An analysis for variance test of normality, Biometrika, 52, 591-611, 1965.

Shirmohammadi, A. and Skaggs, R.: Effect of surface conditions on infiltration for shallow water table soils, Trans. ASAE, 27, 1780-1787, 1984.

Soil Survey Staff: Keys to soil taxonomy, Natural Resources Conservation Service (United States Department of Agricuture), Washington, DC, 2010.

Srinivasarao, C. H., Venkateswarlu, B., Lal, R., Singh, A. K., Kundu, S., Vittal, K. P. R., Patel, J. J., and Patel, M. M.: Long-term manuring and fertilizer effects on depletion of soil organic carbon stocks under pearl millet/cluster bean-castor rotation in western India, Land Degrad. Dev., 25, 173-183, doi:10.1002/ldr.1158, 2014. 
Steinbach, H. S. and Álvarez, R.: Chances in soil organic carbon contents and nitrous oxide emission after introduction of no-till in pampean agroecosystems, J. Environ. Qual., 35, 3-13, 2005.

Strudley, W. M., Green, T. R., and Ascough II, J. C.: Tillage effects on soil hydraulic properties in space and time: State of the science, Soil Till. Res., 99, 4-48, 2008.

Studdert, G. A. and Echeverría, H. E.: Crop rotations and nitrogen fertilization to manage soil organic carbon dynamics, Soil Sci. Soc. Am. J., 64, 1496-1503, 2000.

Studdert, G. A., Echeverría, H. E., and Casanovas, E. M.: Crop pasture rotation for sustaining the quality and productivity of a Typic Argiudoll, Soil Sci. Soc. Am. J., 61, 1466-1472, 1997.

Thapa, G. B. and Yila. O. M.: Farmers' land management practices and status of agricultural land in the Jos Plateau, Nigeria, Land Degrad. Dev., 23, 263-277, doi:10.1002/ldr.1079, 2012.

Thornthwaite, C. W.: An approach toward a rational classification of climate, Geogr. Review, 38, 55-94, 1948.
Velasco, J. L., Sainz Rozas, H., Echeverria, H. E., and Barbieri, P. A.: Optimizing fertilizer nitrogen use efficiency by intensively managed spring wheat in humid regions: Effect of split application, Can. J. Plant Sci., 92, 110, doi:10.4141/CJPS2011-146, 2012.

Voorhees, W. and Lindstrom, M.: Long-term effects of tillage method on soil tilth independent of wheel traffic compaction, Soil Sci. Soc. Am. J., 48, 152-156, 1984.

Watson, K. and Luxmoore, R.: Estimating macroporosity in a forest watershed by use of a tension infiltrometer, Soil Sci. Soc. Am. J., 50, 578-582, 1986.

West, L. T., Miller, W. P., Langdale, G. W., Bruce, R. R., Laflen, J. M., and Thomas, A. W.: Cropping System and Consolidation Effects on Rill Erosion in the Georgia Piedmont, Soil Sci. Soc. Am. J., 56, 1238-1243, 1990.

Wooding, R. A.: Steady infiltration from a shallow circular pond, Water Resour. Res., 4, 1259-1273, 1968.

Zárate, M. and Blasi, A.: Late Pleistocene and Holocene loess deposits of the Southeastern Buenos Aires province, Argentina, Geojournal, 24, 211-220, 1991. 